\title{
CERITA RAKYAT DI KABUPATEN BANJARNEGARA
}

\author{
Khotami Nursa'ah
}

Jurusan Bahasa dan Sastra Jawa, Fakultas Bahasa dan Seni, Universitas Negeri Semarang, Indonesia

\begin{tabular}{l}
\hline Info Artikel \\
\hline SejarahArtikel: \\
\hline Keywords: \\
inventory, folklore
\end{tabular}

\begin{abstract}
Abstrak
Cerita rakyat merupakan kekayaan budaya dan sejarah Bangsa Indonesia. Pada umumnya, cerita rakyat berisi kisah tentang kejadian atau asal muasal suatu tempat. Cerita rakyat merupakan cerita lisan yang telah lama hidup dalam tradisi suatu masyarakat. Di setiap daerah pasti terdapat cerita rakyat yang harus dijaga dan dilestarikan, namun saat ini banyak generasi muda yang tidak mengetahui cerita rakyat dari daerahnya. Seperti di Banjarnegara, banyak cerita rakyat yang tumbuh dan berkembang di wilayah tersebut yang belum diketahui oleh masyarakat khususnya generasi muda, maka perlu dilakukan inventarisasi cerita rakyat di Kabupaten Banjarnegara untuk didokumentasikan dalam bentuk tulisan. Permasalahan dalam penelitian ini adalah: (1) Bagaimana langkahlangkah inventarisasi cerita-cerita rakyat yang ada di Kabupaten Banjarnegara, (2) Bagaimana hasil inventarisasi cerita-cerita rakyat yang ada di Kabupaten Banjarnegara. Tujuan penelitian ini adalah mendeskripsikan langkah-langkah dan hasil inventarisasi cerita-cerita rakyat yang ada di Kabupaten Banjarnegara. Teori yang digunakan dalam penelitian ini adalah teori folklor Danandjaja. Penelitian ini menggunakan pendekatan objektif. Metode yang digunakan adalah metode deskriptif inventarisasi. Penelitian ini menghasilkan simpulan, (1) langkah-langkah inventarisasi cerita rakyat di Kabupaten Banjarnegara dilakukan melalui jalur formal dan nonformal. Jalur formal ditempuh dengan survei di Dinas Pariwisata dan Kebudayaan Kabupaten Banjarnegara, sedangkan jalur nonformal ditempuh dengan observasi di Kecamatan Banjarmangu, Kecamatan Batur, Kecamatan Punggelan, Kecamatan Purwareja Klampok dan Kecamatan Sigaluh, dimana terdapat cerita rakyat Mulabukane Kabupaten Banjarnegara, Dumadine Desa Banjarmangu, Mulabukane Batur, Raden Sam Hoong, Demang Tirtayasa lan Dumadine Desa-desa nang Kecamatan Purwareja Klampok, dan Dumadine Desa Sigaluh. Data cerita rakyat yang telah didapatkan kemudian ditranskripkan dalam bentuk tulisan; (2) hasil inventarisasi cerita rakyat di Kabupaten Banjarnegara berupa transkrip wacana cerita rakyat di Kabupaten Banjarnegara dalam bentuk tulisan berbahasa Jawa ragam Banyumas yang mencakup cerita Mulabukane Kabupaten Banjarnegara, Raden Sam Hoong, Dumadine Desa Sigaluh, Demang Tirtayasa lan Dumadine Desa-desa nang Kecamatan Purwareja Klampok, Mulabukane Batur, dan Dumadine Desa Banjarmangu. Berdasarkan hasil penelitian, perlu adanya studi lanjut dan penyusunan cerita rakyat di Kabupaten Banjarnegara dalam bentuk buku cerita berbahasa Jawa.
\end{abstract}




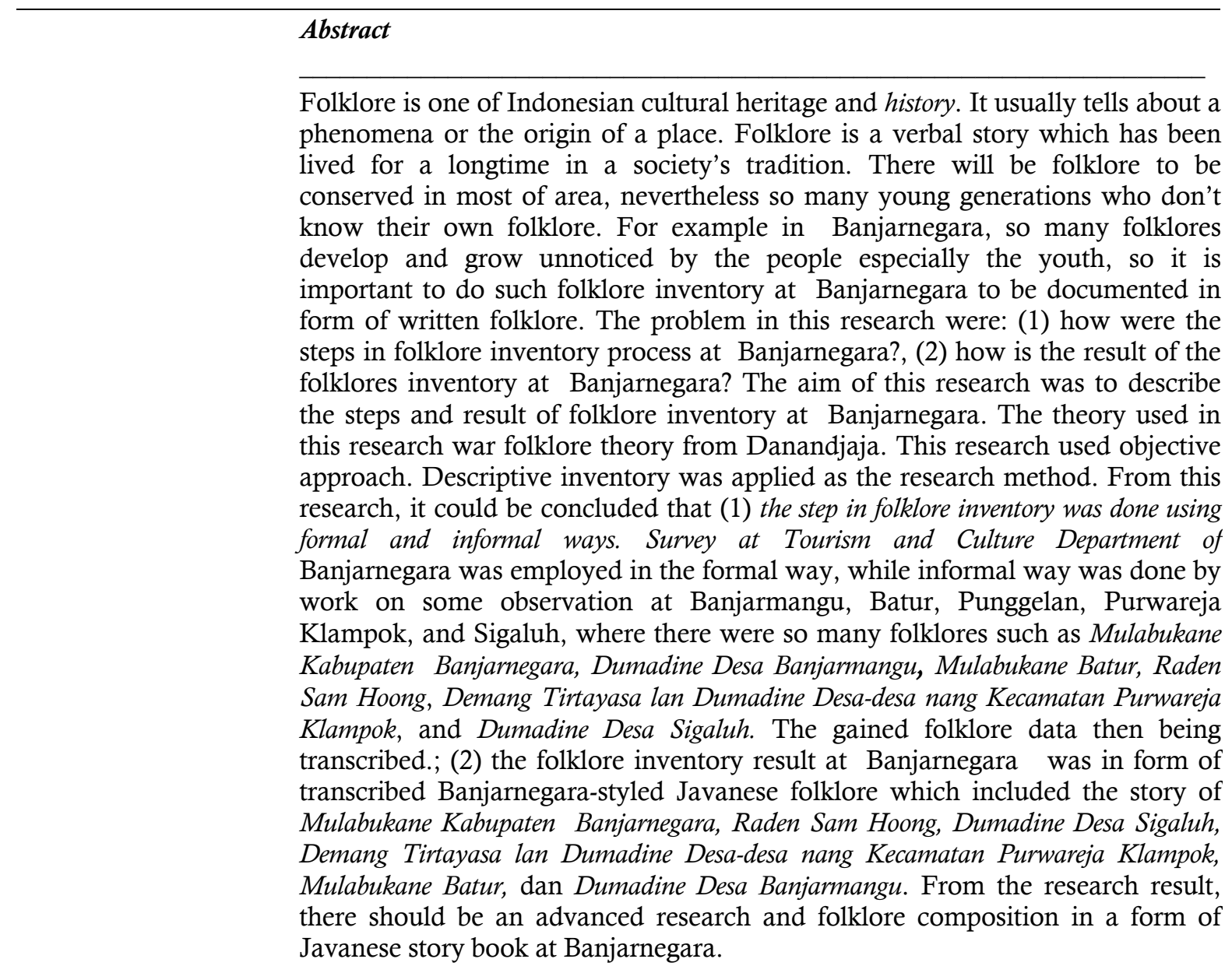

(C) 2016 UniversitasNegeri Semarang

$\bowtie$ Alamatkorespondensi:

Gedung B8 Lantai 1 FBS Unnes

ISSN 2252-6463

Kampus Sekaran, Gunungpati, Semarang, 50229

E-mail: sutasoma@mail.unnes.ac.id 


\section{PENDAHULUAN}

Indonesia merupakan negara yang kaya akan budaya. Setiap wilayah di Indonesia memiliki ciri khas tersendiri seperti makanan, lagu daerah, tarian, hingga cerita rakyat yang berkembang di wilayah tersebut. Karena merupakan ciri khas, jadi pada masing-masing daerah tidaklah sama. Begitu pula dengan cerita rakyat, pada setiap daerah pasti berbeda.

Cerita rakyat menjadi bagian kekayaan budaya dan sejarah yang dimiliki Bangsa Indonesia. Pada umumnya, cerita rakyat mengisahkan tentang suatu kejadian di suatu tempat atau asal muasal suatu tempat.

Cerita rakyat penyampaiannya secara turun temurun dari seseorang kepada orang lain. Cerita yang disampaikan cenderung berubah-ubah sebagian ceritanya, dan mengarah pola yang bersifat rata-rata serta tidak memiliki bentuk yang tetap. Karena cerita rakyat disampaikan oleh orang yang berbeda dari generasi ke generasi, maka tidak dapat dipungkiri bahwa cerita rakyat pada daerah yang sama pun mungkin memiliki versi yang berbeda. Perbedaan versi tersebut sangatlah dimaklumkan karena tidak mungkin suatu cerita akan sama persis padahal penuturnya berbeda. Suatu cerita rakyat pasti mengalami sedikit penambahan maupun pengurangan di dalamnya, namun inti cerita tetap tersampaikan.

Bascom melalui Danandjaya (2007: 50) membagi cerita prosa rakyat dalam tiga golongan besar, yaitu: (1) mite (myth), (2) legenda (legend), dan (3) dongeng (folktale). Mite adalah cerita prosa rakyat yang dianggap benar- benar terjadi serta dianggap suci oleh yang empunya cerita. Mite ditokohi oleh para dewa, atau makhluk setengah dewa. Peristiwa terjadi di dunia lain, atau di dunia yang seperti yang kita kenal sekarang, dan terjadi pada masa lampau. Sedangakn legenda adalah prosa rakyat yang mempunyai ciri-ciri yang mririp dengan mite, yaitu dianggap pernah benarbenar terjadi, tetapi tidak dianggap suci. Berlainan dengan mite, legenda ditokohi manusia, walaupun ada kalanya mempunyai sifat-sifat luar biasa, dan seringkali juga dibantu makhluk-makhluk ajaib. Tempat terjadinya adalah di dunia seperti yang kita kenal kini, karena waktu terjadinya belum terlalu lampau. Sebaliknya, dongeng adalah prosa rakyat yang tidak dianggap benar-benar terjadi oleh yang empunya cerita dan dongeng tidak terikat oleh waktu maupun tempat.

Cerita rakyat merupakan cerita lisan yang telah lama hidup dalam tradisi suatu masyarakat. Cerita rakyat dapat dikategorikan dalam ragam sastra lisan. Menurut Sukadaryanto (2010: 99) sastra lisan adalah karya sastra yang dalam penyampaiannya menggunakan tuturan atau lisan. Karya-karya sastra lisan berwujud prosa (cerita rakyat: mythe, legenda, dan dongeng), puisi (parikan, wangsalan, bebasan, paribasan, saloka, dan isbat), drama (ketoprak, wayang). Minat sastra lisan atau sastra rakyat mulai timbul pada abad ke-18 di Eropa Barat (Teeuw, 1988: 281).

Sastra lisan merupakan kreatifitas manusia yang hidup dalam kelompok masyarakat yang memilikinya dan diwariskan turun temurun secara lisan dari generasi ke generasi. Cerita lisan lahir dari masyarakat 
tradisional yang selalu memegang teguh tradisi lisannya. Cerita lisan bersifat anonim, sehingga sulit untuk diketahui sumber aslinya serta tidak memiliki bentuk yang tetap. Cerita lisan sebagian dimiliki oleh masyarakat tertentu yang digunakan sebagai alat untuk menggalang rasa kesetiakawanan dan alat bantu untuk membuat ajaran sosial budaya yang berlaku di masyarakat tersebut.

Cerita rakyat lahir dan berkembang dalam masyarakat yang tersebar di berbagai pelosok nusantara, termasuk yang lahir dan berkembang di Jawa khususnya pada masyarakat Jawa Tengah.

Di wilayah Provinsi Jawa Tengah yang membawahi wilayah Karesidenan Banyumas, Kedu, Pekalongan, Solo, Pati dan Semarang, masyarakatnya menggunakan bahasa Jawa sebagai bahasa daerah (bahasa ibu). Begitu juga pada cerita rakyat yang berkembang pun menggunakan dialek bahasa Jawa yang beragam pula sebagai medianya. Variasi dialek dalam bahasa Jawa di Jawa Tengah sangatlah beragam, namun secara garis besarnya dapat dipetakan menjadi dua dialek. Dua dialek tersebut yaitu bahasa Jawa dialek Banyumas-an yang berkembang di wilayah Jawa Tengah sebelah barat, dan bahasa Jawa dialek SoloYogyakarta yang berkembang di wilayah Jawa Tengah sebelah timur. Perbedaan penggunaan dialek pada cerita rakyat di Jawa Tengah tidaklah menjadi penghalang pada pengkajian cerita rakyat (Sukadaryanto, 2010: 129).

Di Provinsi Jawa Tengah terdapat salah satu kabupaten yaitu Banjarnegara. Seperti daerah-daerah lainnya, Banjarnegara juga memiliki cerita rakyat yang tumbuh dan berkembang di wilayah tersebut yang mungkin belum diketahui oleh masyarakat.

Banyak masyarakat Banjarnegara sendiri, khususnya generasi muda yang tidak mengetahui cerita rakyat dari daerahnya. Bahkan penelitian tentang cerita rakyat di Kabupaten Banjarnegara masih minim jumlahnya. Penelitian tentang cerita rakyat di Kabupaten Banjarnegara biasanya hanya mengangkat satu cerita saja lalu dilakukan proses analisis. Beberapa penelitian bahkan mengangkat cerita yang sama yaitu Asal-usul Girilangan dan Ki Ageng Giring.

Pada masa sekarang ini arus modernisasi sangatlah deras. Budaya luar dengan mudahnya bisa masuk ke daerah-daerah termasuk Banjarnegara. Hal tersebut didukung dengan teknologi yang semakin canggih sehingga para generasi muda mudah mengakses jalan untuk melihat sesuatu yang sedang booming saat ini. Generasi muda berlombalomba mengetahui dan memiliki apapun yang sedang menjadi tren, seperti tren Korea atau yang biasa dikenal dengan K-Pop yang sedang mendunia pada saat ini. Dengan adanya hal tersebut, lama-kelamaan mereka bisa melupakan jatidiri bangsa Indonesia. Mereka mungkin akan lebih memilih mencari informasi tentang boyband Korea dibanding mencari tahu tentang cerita rakyat dari daerah mereka sendiri.

Kebanyakan masyarakat khususnya generasi muda di Banjarnegara hanya mengetahui cerita-cerita rakyat yang terkenal saja seperti Tangkuban Perahu, Asal-usul 
Banyuwangi, Candi Prambanan, dan ceritacerita lain yang itu semua merupakan cerita rakyat dari daerah lain. Hal ini sangat disayangkan, karena jika generasi muda saat ini tidak mengetahui cerita-cerita rakyat yang ada di daerahnya, bagaimana nasib cerita-cerita rakyat tersebut nantinya. Sedangkan cerita rakyat itu sendiri harus terus tumbuh dan berkembang agar tidak mengalami kepunahan.

Ketidaktahuan generasi muda akan cerita rakyat di daerahnya tersebut timbul karena tidak adanya sarana yang memberikan pengetahuan tentang cerita rakyat di Kabupaten Banjarnegara. Penelitian Inventarisasi Cerita Rakyat di Kabupaten Banjarnegara ini diharapkan dapat menjembatani permasalahan tersebut. Penelitian ini akan mengambil beberapa cerita rakyat di Kabupaten Banjarnegara yang diduga perlu dikenalkan kepada masyarakat Banjarnegara khususnya generasi muda dan nantinya akan dibuat menjadi dokumen yang berisi wacana cerita rakyat di Kabupaten Banjarnegara menggunakan bahasa Jawa dengan dialek lokal Banjarnegara.

Dengan demikian, pengetahuan masyarakat Banjarnegara khusunya generasi muda tentang cerita-cerita yang ada di daerah tempat tinggalnya akan bertambah, dan akan memperkaya khasanah kearifan lokal untuk generasi muda di Banjarnegara. Serta cerita rakyat di Kabupaten Banjarnegara diharapkan tidak hilang tertelan cerita-cerita dari luar Banjarnegara yang lebih terkenal. Permasalahan tentang cerita rakyat Banjarnegara yang mengemuka sangatlah banyak, untuk itu peneliti membatasi dan merumuskan masalah sebagai berikut.

Berdasarkan latar belakang tersebut, maka rumusan masalah dalam penelitian ini adalah: (1) Bagaimana inventarisasi cerita-cerita rakyat yang ada di Kabupaten Banjarnegara? (2) Bagaimana hasil inventarisasi cerita-cerita rakyat yang ada di Kabupaten Banjarnegara?

Tujuan penelitian ini adalah: Mendeskripsikan cerita-cerita rakyat yang ada di Kabupaten Banjarnegara.

Mendeskripsikan hasil inventarisasi cerita-cerita rakyat yang ada di Kabupaten Banjarnegara berupa dokumen wacana cerita rakyat di Kabupaten Banjarnegara dengan bahasa Jawa lokal Banjarnegara.

Teori-teori yang digunakan dalam penelitian ini adalah konsep dasar inventarisasi, cara penulisan buku cerita, unit-unit naratif dan cerita rakyat. Inventarisasi menurut Sugono dkk(2008: 545) adalah pencatatan atau pendaftaran barang-barang milik kantor (sekolah, rumah tangga dsb) yang dipakai dalam melaksanakan tugas. Pengertian kedua, inventarisasi yaitu pencatatan atau pengumpulan data (tentang kegiatan, hasil yang dicapai, pendapat umum, persuratkabaran, kebudayaan dsb). Sedangkan menginventarisasi adalah mencatat atau mendaftar barang-barang milik kantor (perumahan, rumah tangga dsb); mengumpulkan atau mendaftar data. Inventarisasi yang dimaksud dalam penelitian ini adalah inventarisasi pada pengertian kedua, yaitu pencatatan atau pengumpulan. 
Menurut Danandjaya (2007: 13), pada umumnya pengumpulan atau inventarisasi folklor ada dua macam yaitu:

1) pengumpulan semua judul karangan (buku dan artikel), yang pernah ditulis orang mengenai folklor Indonesia, untuk kemudian diterbitkan berupa buku bibliografi folklor Indonesia (baik yang beranotasi maupun tidak),

2) pengumpulan bahan-bahan folklor langsung dari tutur kata orang-orang anggota kelompok yang memiliki folklor dan hasilnya kemudian diterbitkan atau diarsipkan.

Metode pengumpulan untuk inventarisasi macam pertama adalah penelitian di perpustakaan (library research), sedangkan macam kedua adalah penelitian di tempat (field research).

Jenis inventarisasi yang dimaksud dalam penelitian Inventarisasi Cerita Rakyat di Kabupaten Banjarnegara ini adalah jenis invetarisasi macam kedua, yaitu pengumpulan bahan-bahan folklor khususnya cerita rakyat langsung dari tutur kata orang-orang anggota kelompok yang empunya folklor dan hasilnya kemudian diterbitkan atau diarsipkan.

Buku cerita termasuk ke dalam kategori buku bacaan. Buku bacaan adalah buku yang dimaksudkan untuk mendorong minat siswa dalam hal membaca (Pusbuk melalui Mujimin,
2011:7). Langkah-langkah menulis menurut Nurudin (2010: 92-111) terdiri dari tahap pramenulis, merencanakan tulisan, menulis dan merevisi draft, serta menulis akhir.

Struktur cerita dapat diketahui dengan jalan menganalisis cerita melalui peristiwaperistiwa dalam cerita yang terangkai dalam peristiwa-peristiwa naratif yang terbagi ke dalam unit-unit cerita (Sukadaryanto, 2010: 50). Peristiwa dapat diartikan sebagai peralihan dari satu keadaan ke keadaan yang lain (Nurgiyantoro dalam Sukadaryanto, 2011: 20). Berdasarkan pengertian itu, dapat dibedakan kalimat-kalimat tertentu yang menampilkan peristiwa dengan yang tidak. Misalnya, antara kalimat-kalimat yang mendeskripsikan tindakan tokoh dengan yang mendeskripsikan ciri-ciri fisik tokoh (Sukadaryanto, 2010:20).

Cerita rakyat adalah cerita dari jaman dahulu yang hidup di kalangan rakyat dan diwariskan secara lisan. Sugono dkk(2008: 263). Cerita rakyat penyebaran dan pewarisannya dilakukan secara lisan, yakni disebarkan melalui tutur kata dari mulut ke mulut dari satu generasi ke generasi berikutnya. Cerita rakyat bersifat tradisional, yakni disebarkan dalam bentuk relatif tetap atau dalam bentuk standar dan disebarkan diantara kolektif tertentu dalam waktu yang cukup lama. Selain itu, cerita rakyat ada (exist) dalam versi-versi bahkan varian-varian yang berbeda. Hal ini diakibatkan oleh cara penyebarannya dari mulut ke telinga (lisan), biasanya bukan melalui cetakan atau rekaman, sehingga interpolasi (interpolation), dengan mudah dapat mengalami perubahan. Cerita rakyat bersifat anonim, yaitu nama penciptanya sudah tidak diketahui lagi, 
sehingga menjadi milik bersama (collective) dari kolektif tertentu. William R. Bascom (melalui Danandjaya, 2007: 50) membagi cerita prosa rakyat ke dalam tiga golongan besar yaitu mite, legenda dan dongeng. Sedangkan dalam karya yang termahsyur The Psychology of Peoples, Wundt (melalui Propp, 1987: 6) membagi cerita rakyat sebagai berikut:

1) cerita dongeng mitos (Mythologische Fabel marchen)

2) cerita pari-pari tulen (Reine Zaubermarchen)

3) cerita-cerita dan dongeng-dongeng tumbuhan (Biologische Marchen und Fabeln)

4) dongeng binatang tulen (Reine Tierfabeln)

5) cerita-cerita asal usul(Abstammungsmarchen)

6) cerita-cerita dan dongeng jenaka (Scherzmarchen und Scherzjabeln)

7) dongeng-dongeng moral (Moralische Fabeln)

\section{METODE PENELITIAN}

Pendekatan yang digunakan dalam penelitian ini adalah pendekatan objektif, yaitu pendekatan yang menitikberatkan pada teks karya sastra lisan itu sendiri. Pendekatan objektif digunakan untuk mengetahui urutan peristiwa cerita rakyat di Kabupaten Banjarnegara dalam upaya inventarisasi. Metode yang digunakan dalam penelitian ini adalah metode deskriptif inventarisasi. Penelitian Inventarisasi Cerita Rakyat di Kabupaten Banjarnegara ini termasuk dalam penelitian folklore karena yang menjadi objek penelitian adalah cerita rakyat sebagai salah satu bentuk folklore. Untuk memperoleh data, peneliti menggunakan metode penelitian lapangan (grounded research). Peneliti melakukan wawancara warga di beberapa kecamatan di
Banjarnegara mengenai cerita rakyat setempat. Hasil wawancara kemudian dikumpulkan menjadi dokumen.

Data dalam penelitian ini adalah ceritacerita rakyat di Kabupaten Banjarnegara antara lain cerita Mulabukane Kabupaten Banjarnegara, Raden Sam Hoong, Mulabukane Sigaluh, Demang Tirtayasa lan Dumadine Desa-desa nang Kecamatan Purwareja Klampok, Mulabukane Batur dan Dumadine Desa Banjarmangu. Enam cerita rakyat tersebut merupakan cerita yang paling banyak diketahui oleh masyarakat di Banjarnegara. Sumber data dalam penelitian ini berasal dari narasumber melalui kegiatan wawancara. Kegiatan wawancara dilakukan oleh peneliti kepada tokoh masyarakat di mana cerita rakyat itu mengakar dan dipervaya masyarakat. Informasi mengenai cerita rakyat di Kabupaten Banjarnegara. Teknik pengumpulan data yang digunakan adalah wawancara, observasi dan dokumentasi.

Teknik analisis data yang digunakan dalam penelitian ini adalah analisis deskriptif. Data diperoleh dari wawancara mengenai cerita rakyat di Kabupaten Banjarnegara. Setelah memperoleh data, dilanjutkan dengan mencari unit-unit naratif masing-masing cerita. Setelah ditemukan unit-unit naratif cerita-cerita rakyat di Kabupaten Banjarnegara, maka akan dapat disusun cerita-cerita rakyat di Kabupaten Banjarnegara dalam bentuk wacana tulis berbahasa Jawa dengan dialek lokal Banjarnegara.

\section{HASIL PENELITIAN}




\section{Langkah-langkah \\ Cerita Rakyat di Kabupaten Banjarnegara}

Langkah awal peneliti dalam proses inventarisasi cerita rakyat di Kabupaten Banjarnegara bermula dari Dinas Pariwisata dan Kebudayaan Kabupaten Banjarnegara, dilanjutkan dengan observasi dibeberapa kecamatan dengan menemui tokoh masyarakat di kecamatan tersebut. Peneliti melakukan wawancara dengan beberapa narasumber mengenai cerita rakyat yang berkembang di daerahnya,antara lain: Bapak Suwardi dari Kecamatan Sigaluh, Bapak Amir dari Kecamatan Banjarmangu, Bapak Nasirun dari Kecamatan Punggelan, Bapak Djaswin dari Kecamatan Purwareja Klampok dan Bapak Paryono dari Kecamatan Batur.

Setelah mendapatkan data cerita-cerita rakyat di Kabupaten Banjarnegara, selanjutnya dilakukan proses penulisan cerita yang akan disusun menjadi sebuah dokumen. Langkah awal penulisan cerita adalah tahap pramenulis, yaitu pemilihan dan pembatasan topik. Peneliti tidak melakukan tahap ini karena topik sudah ada yaitu dari hasil wawancara dengan narasumber. Peneliti hanya memikirkan gambaran dari topik yang sudah ada.

Tahap yang kedua yaitu merencanakan tulisan, biasanya dengan menyusun gagasan dan membuat outline. Penyusunan gagasan dapat dilakukan dengan cara menulis daftar dan menulis kalimat topik. Pada tahap ini, peneliti membuat unit-unit naratif cerita yang merupakan pokok-pokok dari cerita rakyat yang ada di Kabupaten Banjarnegara. Unit-unit naratif dibuat berdasarkan data hasil wawancara dengan narasumber.

Tahap penulisan selanjutnya adalah menulis dan merevisi draft. Setelah menemukan pokok cerita dan membuat unit-unit naratif, peneliti menuliskan deskripsi cerita-cerita rakyat yang ada di Kabupaten Banjarnegara. Setelah menjadi wacana, peneliti membaca kembali hasil tulisan tersebut dan merevisi beberapa kesalahan. Setelah peneliti merasa mantap dengan tulisan tersebut, selanjutnya akan diajukan kepada pembimbing untuk mendapatkan koreksi yang lebih baik. Setelah mendapat beberapa koreksi, yang dilakukan selanjutnya adalah menulis akhir yang merupakan tahap terakhir dari penulisan cerita.

\section{Hasil Inventarisasi Cerita Rakyat di Kabupaten Banjarnegara}

Hasil inventarisasi cerita rakyat di Kabupaten Banjarnegara yang berhasil peneliti inventarisasikan antara lain adalah cerita Mulabukane Kabupaten Banjarnegara, Raden Sam Hoong, Mulabukane Sigaluh, Demang Tirtayasa lan Dumadine Desa-desa nang Kecamatan Purwareja Klampok, Mulabukane Batur dan Dumadine Desa Banjarmangu.

1) Cerita Rakyat Mulabukane Kabupaten Banjarnegara

Cerita rakyat Mulabukane Kabupaten Banjarnegara merupakan cerita rakyat yang berkembang di daerah Banjarkulon dan Banjarnegara kota. Cerita rakyat Mulabukane Kabupaten Banjarnegara ini menceritakan perjalanan terbentuknya Kabupaten 
Banjarnegara yang bermula dari satu rumah milik Kyai Maliu yang dibangun di daerah sawah yang bentuknya berbanjar di dekat Sungai Merawu. Satu rumah tersebut menarik perhatian banyak orang dan akhirnya mereka ikut membangun rumah di sekitar rumah Kyai Maliu hingga pemukiman itu menjadi Desa Banjar. Desa tersebut termasuk di dalam sebuah kabupaten baru yang merupakan pecahan, dan kabupaten itu bernama Banjar Petambakan. Dengan adanya pergantian pemimpin, Kabupaten Banjar Petambakan dipindahkan ke sebelah barat Kali Merawu dan dinamakan Banjar Watulembu. Terlepas dari kepemimpinan bupati sebelumnya, Kabupaten Banjar Watulembu lalu dipindahkan ke sebelah selatan Sungai Serayu yang semula berupa persawahan. Kabupaten baru tersebut diberi nama Banjarnegara.

\section{2) Cerita Rakyat Raden Sam Hoong}

Cerita rakyat Raden Sam Hoong merupakan cerita rakyat yang berkembang di Desa Sambong Kecamatan Punggelan Kabupaten Banjarnegara. Cerita rakyat Raden Sam Hoong ini menceritakan tentang perjalanan hidup seorang hulu balang dari negeri China yang bernama Raden Sam Hoong yang berguru kepada Ki Ageng Kemuning di sebuah padepokan. Di padepokan tersebut Raden Sam Hoong berguru bersama Mbah Brontok, Raden Nambangan, Raden Aji dan Nyai Pandan Sari. Walaupun satu perguruan, terdapat kedengkian Mbah Brontok kepada Raden Sam Hoong karena lebih menonjol. Mbah Brontok berniat jahat kepada Raden Sam Hoong namun niat itu diketahui oleh Raden Aji. Raden Sam Hoong mengacuhkan ajakan
Mbah Brontok untuk beradu kesaktian. Akhirnya Raden Aji yang yang melayani tantangan dari Mbah Brontok. Pergelutan tersebut berakhir dengan kematian Mbah Brontok dan perasaan bersalah Raden Aji hingga dirinya memilih untuk bertapa dan tidak kembali ke padepokan. Raden Sam Hoong lalu mendapat tugas dari Ki Ageng Kemuning untuk mencari asal cahaya gemilang yang beberapa saat tadi dilihatnya. Raden Sam Hoong berhasil menemukan asal cahaya itu dan mendapat pusaka. Akhirnya, Raden Sam Hoong dijodohkan dengan Nyai Pandan Sari dan hidup di padepokan itu selamanya. Oleh karena Raden Sam Hoong telah melaksanakan tugas dengan baik, maka padepokan tersebut diberi nama Sambong.

3) Cerita Rakyat Dumadine Desa Sigaluh

Cerita rakyat Dumadine Desa Sigaluh ini berkembang di Kecamatan Sigaluh yaitu Banjarnegara sebelah timur. Cerita rakyat Dumadine Desa Sigaluh ini menceritakan tentang kisah Adipati Wargo Hutomo I atau Adipati Wirasaba yang dibunuh karena dianggap telah melanggar perintah Sultan Hadiwijoyo (Sultan Pajang) atas dasar fitnah Putra Demang Toyareka. Awalnya Sultan Pajang menyuruh semua Adipati mengirimkan upeti berupa gadis perawan, lalu Adipati Wirasaba mengirimkan putrinya yang masih perawan namun pernah dinikahkan dengan Putra Demang Toyareka. Putra Demang Toyareka yang merasa dendam kepada Adipati Wirasaba lalu menyebar fitnah. Sultan Pajang terpengaruh oleh fitnah tersebut dan menyuruh utusan untuk membunuh Adipati Wirasaba. 
Sebenarnya Sultan Pajang sempat membatalkan hukuman mati tersebut, namun utusan Sultan salah paham dan tetap membunuh Adipati Wirasaba. Adipati Wirasaba sesaat sebelum dibunuh sedang memakan nasi (sega) sambil berlinangan air mata (luh). Jadilah tempat meninggalnya Adipati Wirasaba tersebut dinamai Sigaluh.

4) Cerita Rakyat Demang Tirtayasa lan Dumadine Desa-desa nang Kecamatan Purwareja Klampok

Cerita rakyat Demang Tirtayasa lan Dumadine Desa-desa nang Kecamatan Purwareja Klampok ini berkembang di Kecamatan Purwareja Klampok yaitu Kabupaten Banjarnegara bagian barat, berbatasan dengan Kabupaten Purbalingga. Cerita rakyat ini menceritakan perjalanan salah seorang pengikut Sultan Agung Mataram yang bernama Demang Tirtayasa yang terpesona dengan kesuburan alam di suatu tempat yang akhirnya dinamakan Purwareja. Perjalanan Demang Tirtayasa dimulai dengan tugasnya menjadi mata-mata untuk mencari keberadaan markas Belanda Kompeni. Sayangnya sebelum Demang Tirtayasa berangkat, dia kehilangan pusakanya yaitu Kudi Cenggarang. Tugasnya sebagai mata-mata beriringan dengan pencarian pusakanya. Setelah Demang Tirtayasa bertapa, dia mendapat ilham bahwa pusakanya berada tidak jauh dengan markas Belanda. Demang Tirtayasa dengan penuh semangat mencari dua hal tersebut. Tempat demi tempat dilewati oleh Demang Tirtayasa, sembari memberi nama tempat-tempat itu berdasarkan apa yang dia lihat dan dia lakukan di tempat tersebut. Sampai pada suatu saat Demang Tirtayasa duduk disebuah batu besar dan mendapati pusakanya tiba-tiba sudah tergeletak di sampingnya. Setelah itu Demang Tirtayasa berkeliling mencari markas Belanda. Akhirnya Demang Tirtayasa berhasil menemukan tenda markas Belanda.

\section{5) Cerita Rakyat Mulabukane Batur}

Diawali dengan kisah seorang raja yang saat itu berkuasa bernama Raja Kejawan. Sang Raja mendengar ada kerusuhan di suatu tempat, maka ia berniat membendung kerusuhan itu supaya tidak sampai ke daerah yang ia pimpin. Dalam upaya membendung kerusuhan tersebut, Raja Kejawan mengutus Ki Bramasari alias Ki Batur untuk memimpin pasukan dalam membendung kerusuhan itu. Ki Batur bersama prajurit berangkat menuju pegunungan Dieng dimana kerusuhan itu sedang terjadi. Akhirnya Ki Batur dan para peajurit bertemu dengan pasukan dari pesisir lor Jawa yang membawa kerusuhan itu. Kedua kubu akhirnya berperang dan berakhir dengan kematian salah satu prajurit Ki Batur. Akibat perang tersebut, banyak prajurit yang terluka termasuk Ki Batur sendiri. Setelah beberapa hari dirawat, Ki Batur akhirnya meninggal. Tempat meninggalnya Ki Batur tersebut lalu dinamakan Batur.

6) Cerita Rakyat Dumadine Desa Banjarmangu

Cerita rakyat Dumadine Desa Banjarmangu berkembang di ibukota Kecamatan Banjarmangu yaitu Desa Banjarmangu. Kecamatan Banjarmangu sendiri berada di Kabupaten Banjarnegara bagian 
utara. Cerita rakyat Dumadine Desa Banjarmangu ini menceritakan tentang penamaan sebuah tempat yang berawal dari pengusiran dua pejuang bernama Baeladah dan Baeloji. Akibat pengusiran itu, keduanya lalu saling menyalahkan dan mereka bertengkar. Pertengkaran berakhir dengan meninggalnya Baeloji yang ditusuk oleh Baeladah lalu dipotong-potong tubuhnya menjadi tiga bagian. Tiga bagian tubuh Baeloji lalu dimakamkan di tiga tempat yang berjauhan. Setelah kejadian itu, Baeladah merasa bersalah dan linglung. Baeladah duduk termangu-mangu di sebuah pertigaan, hingga akhirnya pertigaan itu dan daerah disekitarnya dinamakan Banjarmangu.

\section{SIMPULAN}

Berdasarkan penelitian yang telah dilakukan, dapat diambil kesimpulan sebagai berikut.

Cerita rakyat di Kabupaten Banjarnegara yang populer berada di beberapa kecamatan yaitu di Kecamatan Banjarmangu, Kecamatan Batur, Kecamatan Punggelan, Kecamatan Purwareja Klampok dan Kecamatan Sigaluh dimana terdapat cerita rakyat Mulabukane Kabupaten Banjarnegara, Dumadine Desa Banjarmangu, Mulabukane Batur, Raden Sam Hoong, Demang Tirtayasa lan Dumadine Desa-desa nang Kecamatan Purwareja Klampok, dan Dumadine Desa Sigaluh. Data cerita-cerita rakyat yang telah didapatkan kemudian ditranskripkan dalam bentuk tulisan. Hasil inventarisasi cerita rakyat di Kabupaten Banjarnegara yaitu berupa transkrip wacana cerita rakyat di Kabupaten Banjarnegara dalam bentuk tulisan berbahasa
Jawa dengan dialek lokal Banjarnegara yang mencakup cerita Mulabukane Kabupaten Banjarnegara, Raden Sam Hoong, Dumadine Desa Sigaluh, Demang Tirtayasa lan Dumadine Desa-desa nang Kecamatan Purwareja Klampok, Mulabukane Batur, dan Dumadine Desa Banjarmangu.

Berdasarkan hasil penelitian, maka perlu adanya studi lanjut cerita rakyat di Kabupaten Banjarnegara dan penyusunan cerita rakyat di Kabupaten Banjarnegara dalam bentuk buku cerita berbahasa Jawa dialek banyumasan.

\section{DAFTAR PUSTAKA}

Danandjaya, James. 2007. Folklor Indonesia: Ilmu Gosip, Dongeng, dan lain-lain. Jakarta: Grafiti.

Mujimin. 2011. Telaah Buku Teks. Paparan Perkuliahan: Unnes.

Nurgiyantoro, Burhan. 1998. Teori Pengkajian Fiksi. Yogyakarta: Gadjah Mada University Press.

Nurudin. 2010. Dasar-Dasar Penulisan. Malang: UMM Press.

Propp, V (terjemahan Noriah Taslim). 1987. Morfologi Cerita Rakyat. Kualalumpur: Dewan Bahasa dan Pustaka.

Pusat Bahasa Depdiknas. 2007. Kamus Besar Bahasa Indonesia Edisi Ketiga. Jakarta: Balai Pustaka. 
Khotami Nursa'ah, Bambang Indiatmoko, Yusro Edy Nugroho / SUTASOMA

Sukadaryanto. 2010. Sastra Perbandingan: Teori, Metode, dan Implementasi. Semarang: Griya Jawi.

Teeuw, A. 1988. Sastra dan Ilmu Sastra. Pengantar Teori Sastra. Jakarta: Pustaka Jaya-Girimukti Pasaka. 